DOI 10.37882/2223-2982.2021.06-2.11

\title{
СОСТОЯНИЕ И ВОЗМОЖНЫЕ ПЕРСПЕКТИВЫ РАЗВИТИЯ: СОВЕТСКО-КИТАЙСКИЕ ОТНОШЕНИЯ ПЕРВОЙ ПОЛОВИНЫ 1980-Х ГГ. В ОТРАЖЕНИИ ОТЕЧЕСТВЕННОЙ ПОЛИТИЧЕСКОЙ ЛИТЕРАТУРЫ «ДОПЕРЕСТРОЕЧНОГО» ПЯТИЛЕТИЯ
}

THE STATE AND POSSIBLE PROSPECTS: SOVIET- CHINESE RELATIONS IN THE FIRST HALF OF THE 1980S IN THE REFLECTION OF THE SOVIET POLITICAL LITERATURE OF THE "PRE-PERESTROIKA" 5 YEARS

\section{A. Dorozhkin}

Summary: The article deals with the Soviet-Chinese relations in the first half of the 1980s, when there was a gradual trend towards a cautious normalization of these relations. The direct subject of the research of this article is the reflection of Chinese themes in the Soviet political literature of this period, with a special focus on the current state and possible prospects for the development of relations between Moscow and Beijing. The authors of the relevant publications in the first half of the 1980s were Soviet diplomats, journalists, and in some cases representatives of the Soviet party nomenclature. As a rule, it was about professional sinologists; some of the works were partly memoirs. The analysis of the publications allows us to distinguish two stages in the interpretation of Chinese topics by Soviet political literature of the five "pre-perestroika" years. The first of them (1981-1982) maintained a negative ratings when considering Chinese subjects in Soviet political literature - especially negatively evaluated the foreign policy of the PRC; when interpreting the internal situation of the country, some changes for the better were indicated very carefully. At the second stage, which began around the middle of 1982, the intensity of anti-Maoist propaganda in the USSR gradually weakens, which is reflected in the pages of socio-political literature. The softened tone of publications and the more restrained nature of criticism indicate a trend towards improvement in bilateral relations. This process is, however, uneven, partly intermittent - 1984 was marked by a certain increase in the critical tone of publications about the PRC, and this is more noticeable in political literature than in periodicals. This situation reflected both difficulties in the process of negotiations on normalization of relations, serious differences in the positions of the parties on a number of issues, and strained relations between the China and some "third countries" that had close ties with the USSR.

Keywords: Soviet-Chinese relations, China, USSR, politics, propaganda, normalization, "pragmatics", confrontations.
Дорожкин Андрей Геннадьевич Д.и.н., профессор, ФГБОУ ВО «Магнитогорский государственный технический университет»

andrew-67@mail.ru

Аннотация: Объект исследования данной статьи - советско-китайские отношения в первой половине 1980-х гг., когда постепенно наметилась тенденция к осторожной нормализации этих отношений. Непосредственный предмет исследования - отражение в советской политической литературе указанного периода китайской тематики с особым акцентом на тогдашнее состояние и возможные перспективы развития отношений между Москвой и Пекином. Авторами соответствующих публикаций в первой половине 1980-х гг. выступали советские дипломаты, журналисты-международники, в отдельных случаях - и представители партноменклатуры. Как правило, речь шла при этом о профессиональных китаеведах; некоторые работы носили мемуарный характер. анализ рассмотренных публикаций позволяет выделить два этапа в трактовке китайской тематики советской политической литературой пяти «предперестроечных» лет. На первом из них (1981-1982 гг.) в целом сохранялся негативный настрой при рассмотрении китайских сюжетов советской политической литературой - особенно отрицательно оценивалась внешняя политика КНР; при интерпретации же внутреннего положения страны весьма дозировано и осторожно указывалось на некоторые изменения к лучшему. На втором этапе, начавшемся примерно в середине 1982 г., накал антимаоистской пропаганды в СССР постепенно слабеет, что находит отражение и на страницах общественно-политической литературы. Смягчившийся тон публикаций, более сдержанный характер критики - проявление тенденции к улучшению отношений. Этот процесс шел неровно, отчасти прерывисто 1984 год отмечен некоторым усилением критического тона публикаций 0 КНР, и в публицистических трудах это проявляется заметнее, чем в периодике. Такое положение отражало как трудности процесса переговоров о нормализации отношений, серьезные различия в позициях сторон по ряду вопроСов, так и напряженные отношения КНР с некоторыми третьими странами, имевшими тесные связи с СССР.

Ключевые слова: Китай, СССР, политика, пропаганда, нормализация, «прагматики», конфронтация. 


\section{Введение}

A ктуальность исследования связана с исключительной важностью как исторического опыта советско-китайских отношений для современной России, так и изучения истории советской пропаганды, в которой с середины 1960х гг. на протяжении двадцати лет не последнюю роль играло китайское направление. Первая половина 1980х гг. - крайне неоднозначный период в истории взаимоотношений между Москвой и Пекином. С одной стороны, в эти годы давали о себе знать конфронтационные тенденции, столь отчетливо проявившиеся в предшествующие два десятилетия; с другой - наметились некоторые признаки «потепления» в двусторонних отношениях, что нашло отражение и в выступлениях руководителей СССР, и в материалах советской периодики, и в политической литературе указанного периода. Анализу трактовки последней состояния и возможных перспектив развития этих отношений посвящена предлагаемая статья.

Советско-китайский раскол 1960-х - 1980-х гг., один из крупнейших за всю историю мирового коммунистического движения, вызвал к жизни весьма обширный поток литературы. Но, к сожалению, анализу отражения этой темы, как и попыток преодоления раскола, в советской политической литературе, уделено сравнительно немного внимания. В период сохранявшегося еще разрыва между Москвой и Пекином в СССР выходили аналитические статьи, как и рецензии на отдельные публикации, посвященные истории и текущему состоянию советско-китайских отношений, в т.ч. применительно к периоду первой половины 1980-х гг., когда наметилась осторожная тенденция к их нормализации [27; 30]. 3аслуживает внимания коллективная монография российских историков [23], отдельные части которой связаны с интересующей нас темой. Так, в статье Н.Л. Мамаевой дан общий обзор современного состояния российского китаеведения [20]; определенное внимание в ней уделено анализу работ Б.Т. Кулика об истории советскокитайского раскола [17] и В.Н. Усова, посвященной политическому развитию КНР как раз в 1976 - 1984 гг. [28]. Но, подробно рассматривая монографию Б.Т. Кулика, Н.Л. Мамаева все же специально не остановилась на трактовке этим исследователем причин поворота к нормализации советско-китайских отношений в первой половине 1980х гг. и постепенной эволюции советских пропагандистских установок в отношении КНР [20, с. 31-35]; в работе же В.Н. Усова основное внимание сконцентрировано на внутреннем развитии КНР второй половины 1970x - начала 1980x гг. В статье Т.Г. Герасимовой затронуты предыстория и начало нормализации советско-китайских отношений и одновременно отмечена замедленная реакция историков тогдашнего СССР на наметившиеся изменения, указаны причины такого положения [11, с. 141-142]. Непосредственно системе советской внеш- неполитической пропаганды посвящено основательное исследование Л.В. Силиной; определенное внимание в нем уделено и рассмотрению китайского направления в данной системе [26, с. 39-51]. На собственно проблемах поиска путей к нормализации отношений между СССР и КНР специально остановились Б.Т. Кулик и В.П. Федотов [17; 29], а также Е.П. Бажанов в разделе обобщающей работы по истории, современному состоянию и перспективам развития российско-китайских отношений [25, с. 256-272] . В недавних фундаментальных работах Ю.М. Галеновича подробно рассматриваются причины, проявления и характер нормализации советскокитайских отношений в 1980-е гг. [8; 9], но в круг задач автора не входил непосредственно анализ трактовки китайской политики советской публицистической литературой указанного периода. Наконец, определенное внимание отражению советско-китайских отношений в отечественной публицистике и художественной литературе 1970-х - 1980-х гг. уделил и автор предлагаемой статьи [12]. В рамках же данной работы предполагается специально остановиться на интерпретации в первой половине 1980-х гг. советскими авторами трудов политологического характера таких вопросов, как внутреннее положение тогдашней КНР, ее внешнеполитический курс, но особенно - текущее (на тот момент) состояние и возможные пути будущего развития отношений между Москвой и Пекином. Соответствующие публикации, несомненно, воздействовали на общественное мнение позднего СССР и оказывали определенное влияние на политику руководства страны по отношению к бывщему союзнику, надолго ставшему противником.

\section{Материалы и методы}

В рамках данной статьи представляется целесообразным рассмотреть отражение в советской политической литературе указанного периода характера отношений между двумя крупнейшими социалистическими странами - Союзом Советских Социалистических Республик и Китайской Народной Республикой. Основным источником предлагаемой работы являются труды советских журналистов-международников и дипломатов, связанных по роду профессиональной деятельности с Китаем, а также справочные издания по КНР первой половины 1980-х гг. и сборники публикаций по КНР, выпускавшиеся в Советском Союзе в пропагандистских [22] и отчасти в исследовательских [13] целях. Привлекалась и периодика, в т.ч. научная (журнал «Проблемы Дальнего Востока), но ее роль в контексте выбранной темы не была определяющей - всесторонний анализ отражения проблемы в прессе (как и в исследовательской литературе) требует отдельного изучения. Необходимо отметить, что часть использованных автором источников во многом носит мемуарный характер; в то же время М.И. Яковлев и Л.Н. Кутаков [31; 18] писали свои труды с учетом текущей ситуации в советско-китайских отношениях; первый 
из указанных авторов к тому же являлся очевидцем раннего этапа дэнсяопиновских реформ - его работа содержит поэтому и интересный, основанный на собственных наблюдениях, материал о повседневной жизни КНР начала 1980-х гг., часто при прямом сопоставлении с тем, что доводилось наблюдать в Китае автору в предыдущие десятилетия.

Методологическую основу данной статьи составляют положения коммуникативной теории. Последняя рассматривает пропаганду как важное средство политической коммуникации, в т.ч. власти с обществом, осуществляемое с помощью вербальных и невербальных средств. При этом в процессе анализа источникового материала автором статьи применяются научные принципы историзма, объективности, всесторонности и системности. Работа базируется на следующих общенаучных и общеисторических методах:

- идеографический, выражающийся в описании основного содержания использованных источников, выделении в них элементов, отражающих как тенденции к «потеплению» в советско-китайских отношениях «предперестроечных» лет, так и свидетельствующих о сохраняющихся тенденциях конфронтационного характера;

- метод периодизации, согласно которому изучение советской политической литературы первой половины 1980-х гг. осуществляется в рамках конкретного периода, что позволяет выявить и начало новых тенденций при рассмотрении интересующей темы в использованных автором публикациях «предперестроечных» лет;

- историко-системный, рассматривающий советско-китайские отношения вообще и отражение их в отечественной политической литературе первой половины 1980-х гг. в особенности в качестве целостной системы, подверженной противоречиям и колебаниям;

- историко-сравнительный, позволяющий сопоставлять взгляды и оценки, содержащиеся в использованных материалах;

- историко-генетический, дающий возможность проследить противоречивые тенденции в отношениях между Москвой и Пекином, находившие в «предперестроечное» пятилетие отражение в анализируемых автором трудах.

\section{Результаты}

В самом начале 1980x гг. в общем и целом сохранялась прежняя тональность в издаваемых в СССР материалах по китайской тематике. Как и раньше, внешняя политика пекинского руководства сурово осуждалась за антисоветизм, гегемонизм, сотрудничество с империалистическими кругами Запада и политическими силами «третьего мира», рассматривавшимися Москвой в каче- стве реакционных, а также за раскольническую деятельность в международном коммунистическом движении [1; 3; 24]. Весьма критически оценивалось и внутреннее положение в КНР; победа «прагматиков» в борьбе за власть в партии и стране, развернувшейся после смерти Мао Цзэдуна, отнюдь не привела к снижению накала антимаоистской пропаганды в Советском Союзе; напротив, «прагматики» во главе с Дэн Сяопином оценивались Москвой как наиболее проимпериалистически, прозападно настроенные деятели, сторонники «блокирования с империализмом» на антисоветской основе и создания единого фронта борьбы против СССР в глобальном масштабе; внутренняя же их политика, хотя прямо и не характеризовалась как курс на реставрацию капитализма в Китае, тем не менее, истолковывалась как антисоциалистическая по сути, создающая угрозу «социальным завоеваниям китайского народа» [10, с. 104; 19]. В то же время ряд авторов, в т.ч. известный советский политолог Ф.М.Бурлацкий, отмечали, что едва ли правящие круги КНР согласятся на демонтаж социализма в стране и ослабление своего контроля над экономической сферой общественной жизнедеятельности - неизбежное следствие такого демонтажа [2, с. 367].

Вместе с тем в советской литературе уже в начале 1980х гг. звучали и несколько иные нотки при рассмотрении внутренней политики дэнсяопиновского руководства. Так, видный китаевед, журналист-международник М.И. Яковлев в своей книге, отчасти носящей, о чем уже упоминалось, мемуарный характер, остановился на некоторых изменениях во внутренней жизни Китая, характер которых тогдашнему советскому читателю было бы трудно оценивать иначе, нежели в позитивных тонах. Автор отметил в связи с этим перемены в самом облике Пекина и повседневной жизни населения китайской столицы - большую, по сравнению с годами «культурной революции», раскрепощенность сознания и поведения пекинцев, отсутствие мелочных стеснений и регламентаций в вопросах быта, одежды и времяпрепровождения, некоторые новшества в подаче материала телепередач и в демонстрации документальных кинофильмов (в последнем случае М.И.Яковлев обратил внимание и на демонстрацию кадров, относящихся к советской повседневности, попутно отметив, впрочем, и тенденциозность в подборе материала) [31, с. 294-300]. Советский журналист вместе с тем, продолжая тематику своих публикаций в «Литературной газете» за 1980 г., указал на начавшееся в КНР переосмысление «культурной революции», ее значения и последствий, а отчасти - и роли самого Мао в истории коммунистической партии и страны в целом [31, c. 304-307]. Об этом же идет речь в обобщающем труде О.Б. Борисова (О.Б.Рахманина), предназначенном, прежде всего, для партактива, лекторов и пропагандистовмеждународников. В ней к числу позитивных изменений отнесены более регулярный созыв сессий Всекитайского собрания народных представителей (ВСНП), также как 
и пленумов ЦК КПК и партконференций на местах, возобновление работы общественных организаций, фактически бездействовавших в годы «культурной революции», проведение прямых выборов в органы власти уездного уровня [1, с. 355]. Но основной акцент сделан все же на другом - на формальном характере большинства перемен, трудностях и издержках социального характера, деморализации значительной части населения, а также росте настроений разочарования и апатии [1, с. 355].

Следует отметить, что осторожное признание позитивных перемен во внутренней жизни постмаоцзэдуновского Китая в сочетании с жесткой критикой его Внешней политики прозвучало еще на XXV1 съезде КПСС $[21$, c. 10], и это определило во многом оценки текущего положения в КНР примерно на ближайшие после съезда полтора года - далее уже наметился спад антимаоистской кампании в Советском Союзе, о чем речь еще впереди. Но весьма осторожные намеки на перемены во внутренней жизни постмаоцзэдуновской КНР можно было заметить в советской публицистической и справочной литературе и ранее, еще в конце 1970х гг., сразу же после укрепления позиций Дэн Сяопина в руководстве страной. Так, в ежегоднике «Китайская Народная Республика: политика, экономика, идеология» за 1979 г. отмечалось начало в стране по инициативе Дэн Сяопина кампании «за раскрепощение сознания» и в связи с этим обозначены были существенные ее отличия от политикоидеологических кампаний маоцзэдуновской эпохи. Так, указывалось, что в ходе кампании с конца 1978 г. запрещалось наклеивание ярлыков на идейных оппонентов, допускалась несколько большая свобода выражения мнений [14, с. 67]. Эта кампания, как и другие мероприятия, связанные с решениями 3-го пленума ЦК КПК 11-го созыва (декабрь 1978 г.) и положили начало в Китае, по словам Си Цзиньпина, «периоду реформ и открытости», продолжающемуся поныне [8, с. 50, 58]. В советской же публицистике конца 1970х гг., как и в литературе первых лет следующего десятилетия, подчеркивалась неправомерность характеристики происходящих изменений как «демаоизации» (что не противоречит и официальным оценкам Пекина!) и вместе с тем не переоценивалась степень либерализации политического режима в стране. Специализировавшиеся в тогдашнем СССР на обличении маоизма публицисты Гао Линвэй (В.С. Куликов) и Н.Н. Солнцев акцентировали внимание на пресечении антимаоистских тенденций, стихийно обнаружившихся в ходе кампании по «раскрепощению сознания» [10, с. 201-202], а М.И. Яковлев многозначительно подчеркнул укрепление репрессивно-карательных органов государства в КНР начала 1980x гг. - дэнсяопиновская либерализация сему отнюдь не препятствовала [31, с. 300]. Об этом же шла речь и в работе О.Б. Борисова [1, с.365367]. При этом в начале 1980-х гг. продолжали выходить и работы, по-прежнему безоговорочно бичующие как внешнюю, так и внутреннюю политику преемников Мао
Цзэдуна. Наглядный пример тому - иллюстрированное издание «Китай: стены и люди», составленное только что упомянутыми Гао Линвэем и Н.Н. Солнцевым, авторами сценариев ряда фильмов резко антимаоистской направленности («За стеной страха», «Маоизм - трагедия Китая», «Поджигатели из Поднебесной» и др.), вышедших в 1970x гг. и не раз демонстрировавшихся по советскому телевидению. Данное издание включает в себя кадры из этих кинофильмов и снабжено развернутыми комментариями.

В целом до середины 1982 г. не было оснований говорить об ослаблении накала антимаоистской пропаганды в СССР - имели место лишь довольно слабые, едва заметные тенденции к более взвешенному и менее одностороннему освещению внутренней жизни КНР. Примерно с середины 1982 г. антимаоистская кампания в Советском Союзе слабеет, количество критических материалов в прессе сокращается. Это отражало наметившиеся уже изменения к лучшему во взаимоотношениях между Москвой и Пекином. На причинах этих изменений подробно остановился Б.Т. Кулик (Б.Т. Бацанов, он же Б.Т. Колосков) уже на рубеже XX-XXI вв. Основные из этих причин сводились к ослаблению идеологической конфронтации между двумя крупнейшими «странами социализма» (дэнсяопиновские реформы и курс на сближение с Западом во многом обессмыслили и дезавуировали прежние обвинения китайской стороны в адрес СССР, касавшиеся «буржуазного перерождения» Советского Союза и его стремления «сговориться» с США против КНР), объективной заинтересованности победивших в Китае «прагматиков» в снижении градуса конфронтации с СССР в целях некоторого уменьшения военных расходов и направления высвободившихся средств на нужды поступательного экономического развития страны, включая и те сектора экономики, которые ранее не были «фаворитами» правительственной экономической политики, определенному разочарованию в масштабах экономической помощи Запада в качестве своего рода платы за эскалацию антисоветизма при одновременном сохранении противоречий с западными державами, особенно с США. Возможности развития дружбы и сотрудничества с последними серьезно лимитировались сохранявшейся тайваньской проблемой [17, с. 592-594]. Крупнейший современный российский китаевед Ю.М. Галенович отводит ей особое значение - нежелание Вашингтона идти на уступки Пекину в корректировке «особых отношений» с Тайбеем, фактически сохранившихся у США и после официального признания ими КНР в 1979 г., вызвало сильнейшее недовольство Дэн Сяопина и обусловило его согласие летом 1982 г. пойти на некоторое улучшение отношений с Москвой [9, с. 144-146]. И именно с лета 1982 г. антимаоистская кампания в советской прессе была значительно ослаблена и пошла на убыль.

Если же говорить о публицистике, то и в 1982 г. по 
инерции продолжалось еще издание трудов, в которых в полной мере сохранялись прежние оценки как внутренней, так и внешней политики пекинского руководства. В связи с этим можно выделить уже упомянутую работу О.Б. Борисова, как и переведенную на русский язык очередную антимаоистскую публикацию венгерского политолога Ф. Варнаи, а также и сборники трудов по истории и современному состоянию отношений КНР с сопредельными странами [1; 3; 13]. Как и раньше, в 1982 - 1983 гг. продолжалась, в т.ч. и на научном уровне, полемика с китайской историографией по отдельным историческим вопросам, в т.ч. касающимся обстоятельств установления российско-китайской границы на отдельных ее участках, роли Китая в жизни различных народов Дальнего Востока и Центральной Азии, вопросов русского проникновения в соответствующие регионы и значения этого проникновения для проживающих там народов [16]. Вместе с тем целый ряд анонсированных ранее трудов антимаоистской направленности в 1980x гг. не вышел, что, несомненно, отражало тенденцию к начавшемуся «потеплению» советско-китайских отношений. Так, не появились в печати уже подготовленные Институтом Дальнего Востока АН СССР к публикации двухтомник по истории советско-китайских отношений, двухтомник, посвященный политике КНР по отношению к «развивающимся странам», как и монография Д.М. Поспелова и Е.Д. Степанова об антивьетнамской политике КНР в 1960-х начале 1980-х гг. [30, с. 41]. Точно также и издававшийся с 1969 г. сборник критических материалов по КНР с выразительным названием «Опасный курс» [22], после 1981 г. уже не выходил, а очередной выпуск ежегодника «КНР: политика, экономика, идеология» был издан с большой задержкой. Если в 1970x гг. он обыкновенно издавался через год - максимум через два после событий того года, которому был посвящен соответствующий выпуск, то сборник материалов за 1980 г. появился только четыре года спустя. В нем достаточно сдержанно оценивались изменения внутриполитического характера в КНР, имевшие место в тот год, но заметно было определенное снижение тона критических высказываний при рассмотрении как внутри-, так отчасти и внешнеполитических мероприятий победившей группировки «прагматиков». Отмечались значительные проблемы в отношениях Пекина с СССР, СРВ, ЛНДР, МНР, Кубой, а также с Албанией [15, с. 127-132]; вместе с тем довольно сдержанно оценивались взаимоотношения КНР с восточноевропейскими странами «социалистического содружества» при одновременном указании на ограниченный характер связей КНР с ними. Здесь, как и раньше, исключение составляли лишь Румыния. Югославия и Северная Корея [15, с. 133134]. В отличие от выпусков прежних лет, не особенно акцентировалось внимание на попытках китайского руководства создать единый антисоветский фронт в глобальном масштабе, и отсутствовали резкие выпады (в т.ч. персонального характера) в адрес «пекинских гегемонистов» - притом, что непосредственно в 1980 г. подобного рода нападки в изобилии встречались в советской периодике.

Точно также, в отличие от более ранних выпусков названного сборника, не особенно подчеркивалось «блокирование Пекина с империализмом» - отношения КНР с западными державами, а также с Японией интерпретировались в целом как расширение сотрудничества, но вместе с тем давалось понять, что отношения эти вовсе не были столь безоблачными, как то можно было бы предполагать на основании некоторых пропагандистских сентенций конца 1970х гг. Так, применительно к китайско-американским отношениям указывалось, что их и в 1980 г. по-прежнему омрачал тайваньский фактор; указывалось также, что утвержденная тогдашним президентом США Дж. Картером «директива № 59» включала в себя подготовку ядерных ударов по военным объектам в КНР. Пекин и большинство стран Западной Европы по-прежнему разделял вопрос о «детанте» с СССР [15, с. 136-140]. Указывалось также на наличие в США опасений в связи с возможным чрезмерным усилением KHP [15, с. 140-141]. Следует отметить, что об этом советская политическая литература (как и периодика) писала и раньше [2, с. 356]; забегая вперед, можно констатировать, что нынешнее китайско-американское соперничество, на предыстории и сегодняшнем состоянии которого подробно остановился Ю.М. Галенович в своих недавних основательных исследованиях [6; 7], подтверждает, по сути дела, предположения, высказывавшиеся советской публицистикой еще в 1970-1980е гг.

При обращении же к недавней истории советско-китайских отношений и в 1983-1985 гг. полностью сохранялись интерпретации, принятые в отечественной публицистике 1960x - 1970x гг.; ответственность за ухудшение отношений между СССР и КНР по-прежнему возлагалась на китайскую сторону, подчеркивались усилия Москвы по нормализации отношений, не находившие, однако, должного отклика в Пекине [5, с. 138-140, 149-150; 4, с. 286-319]. Вместе с тем в литературе тех лет, в т.ч. мемуарной, налицо было уже явное снижение обличительного тона при обращении к сюжетам жизни постмаоцзэдуновского Китая - показательна в этом отношении вышедшая в 1983 г. книга советского дипломата Л.Н. Кутакова [18, с. 197-224]. Это отражало отмеченное уже общее ослабление накала антимаоистской пропаганды в СССР, ставшее в 1983 г. особенно заметным. Неизменным при этом оставалось твердое выражение готовности к улучшению советско-китайских отношений, «но не за счет третьих стран» - данная оговорка, частая для первой половины 1980x гг., связана была с характером условий нормализации, выдвигавшихся тогдашними пекинскими лидерами.

Наиболее подробно на специфике советско-китайских отношений в первой половине 1980х гг. остано- 
вился видный отечественный синолог О. Владимиров (уже упоминавшийся О.Б. Рахманин), занимавший также в 1968 - 1986 гг. пост первого заместителя заведующего отделом ЦК КПСС по связям с коммунистическими и рабочими партиями социалистических стран [25, с. 264]. Собственно, его труд представлял собой дополненное и частично переработанное издание более ранней его (в соавторстве с Б.Т. Колосковым (Б.Т. Бацановым)) обобщающей работы по истории советско-китайских отношений в послевоенные десятилетия. На сей раз изложение материала в книге было доведено до середины 1980х гг. и именно последняя глава монографии представляет особенный интерес в контексте предлагаемой статьи. Существенно при этом принять во внимание, что сам автор стоял на жестких антипекинских позициях и весьма критически оценивал внутреннюю и внешнюю политику дэнсяопиновского руководства. Это проявилось и в уже рассмотренной его работе о внутренней и внешней политике КНР 1970х гг., а монография 1984 г. в целом сохранила прежние оценки, базирующиеся на установках XXV1 съезда КПСС. Автор и два года спустя рассматривал политику Дэн Сяопина как «правопрагматическую модификацию маоизма», создающую идеологическую основу «блокирования Пекина с империализмом и практически со всеми разновидностями оппортунизма» [4, с. 292]. К этому можно добавить, что в вышедшем тогда же справочном издании о КНР, уже рассмотренном нами, говорилось о расширении в 1980 г. связей КПК «С некоторыми европейскими компартиями», исключительно еврокоммунистического толка (сам термин «еврокоммунизм» при этом не употреблялся) [15, с.145-146]. Этот тезис конкретизировала одна из публикаций в последнем, одиннадцатом выпуске сборника «Опасный курс», представлявшая собой перепечатку из журнала «Новое время» анонимной статьи «Пекин меняет тактику», и приуроченная, как и оригинал, к визиту в КНР в ноябре 1980 г. делегации компартии Испании во главе с ее генсеком С. Каррильо, одним из виднейших представителей «еврокоммунизма» [22, с. 78-84].

Говоря о состоянии советско-китайских отношений в первой половине 1980x гг., О. Владимиров отметил в качестве положительной тенденции рост торгового оборота между двумя странами, возобновление приграничной торговли, определенное развитие контактов в таких областях, как спорт, обмен студентами, взаимными визитами в СССР и КНР делегаций разного уровня. Позитивно оценил автор и проведение между Москвой и Пекином политических консультаций [4, с.307]. Вместе с тем О. Владимиров подчеркнул, что китайское руководство по-прежнему ставило нормализацию политических отношений в зависимость от устранения «трех больших препятствий» (сокращение советского военного присутствия на границе с КНР, а также вывод советских войск из Афганистана и Монголии, а вьетнамских - из Кампучии (Камбоджи)), что в указанный период неизменно встре- чало отрицательный ответ советской стороны. Постоянное заострение вопроса о «трех больших препятствияХ» китайской стороной предопределило фактически безрезультатный итог третьего (осень 1983 г.) и и четвертого (весна 1984 г.) туров упомянутых политических консультаций [4, с.307, 310-311, 318]. Следует отметить, что в дальнейшем такая трактовка значения упомянутых консультаций подверглась пересмотру - видный советский китаевед и дипломат В.П. Федотов склонен был уже в начале XX1 в. давать им положительную оценку, находя, что они сыграли немаловажную роль в последующей нормализации двусторонних отношений [29, с. 471-481; 11, c. 141].

1984 г.. по замечанию О. Владимирова, вообще был отмечен не только сохранением, но и эскалацией темы антисоветизма в печати КНР, в выступлениях официальных лиц. При этом автор, воспроизводя точку зрения, высказанную в более ранней своей работе, отметил общность взглядов на СССР всех пекинских лидеров [4, с. 318-317], проиллюстрировав это их высказываниями о Советском Союзе, относящимися уже к 1983-1984 гг. Так. Ху Яобан в беседе с делегацией шведских коммунистов, отрицал социалистический характер общественного строя СССР. В таком же духе выразился будущий министр иностранных дел КНР (а тогда - заместитель министра) Цянь Цичэнь в интервью, данном американскому журналисту. В связи с этим уместно напомнить, что в СССР не было официального отлучения Китая от социализма, а Л.И. Брежнев в своем выступлении на XXV1 съезде КПСС, как и в ташкентской речи, произнесенной им в марте 1982 г., подтвердил социалистический характер социального строя КНР, что, по мнению ряда современных исследователей, способствовало укреплению тенденции к нормализации отношений между двумя странами [25, с. 264266]. При этом сам Ху Яобан, как указал О. Владимиров, признал осенью 1983 г. на пленуме ЦК КПК господство «атмосферы идеологической неразберихи» в рядах правящей в КНР партии. Нельзя, естественно, исключать, что делая свое упомянутое заявление шведской делегации, генсек ЦК КПК просто маневрировал - Ю.М. Галенович называет Ху Яобана убежденнейшим сторонником нормализации советско-китайских отношений, основательно конкретизирует и аргументирует эту точку зрения [9, с. 138-140, 144, 149-153], да и советская периодика с 1983 г. завуалировано давала понять, что позиция генерального секретаря ЦК КПК является, как минимум, наименее антисоветской в сравнении с другими лидерами Китая.

Как и советская пресса весной-летом 1984 г., О. Владимиров указал на эскалацию напряженности на китайско-вьетнамской границе с апреля 1984 г., отнюдь не благоприятствовавшую нормализации отношений между Москвой и Пекином. Автор подробно рассмотрел широкое и разностороннее сотрудничество КНР с западными державами и Японией в первой половине 1980x 
гг. [4, с. 338-361], уделив особое внимание отношениям Китая с США, находившимися в то время в состоянии «обостренной холодной войны» с Советским Союзом. О. Владимиров указал на идентичность позиций Пекина и Вашингтона по ряду вопросов международной жизни, в т.ч. и тех, что были связаны с пресловутыми «тремя большими препятствиями» (о тождестве взглядов США и КНР на соответствующие вопросы в 1983-1984 гг. постоянно говорили пекинские лидеры и советская пресса, обычно воздерживаясь от резких комментариев на сей счет, упоминала об этих их суждениях - О. Владимиров высказывался в данном случае несколько более «раскованно»). Более «раскованно» советский китаевед высказался и о визите тогдашнего президента США Р. Рейгана в КНР, состоявшемся 26 апреля - 1 мая 1984 г. и в целом весьма сдержанно комментировавшемся на страницах советских газет. О. Владимиров, признавая наличие ряда разногласий между Пекином и Вашингтоном по многим вопросам, отметил в тоже время стремление сторон особо не выпячивать эти разногласия, в т.ч. по тайваньской проблеме [4, с. 350]. Он указал, что желая обеспечить себе свободу маневра в отношении Советского Союза, китайские руководители предпочли не присоединиться открыто к наиболее одиозным антисоветским тирадам заокеанского гостя, расточаемым Р. Рейганом во время визита, но, как и ранее, и позднее, воздержались от резкой критики американской политики там, где позиции двух стран расходились, допуская вместе с тем антисоветские заявления по собственной инициативе [4, с.348349].

\section{Выводы}

Подводя итоги, можно отметить, что применительно к первой половине 1980-х гг. допустимо условно выделить два этапа в трактовке советско-китайских отношений политической литературой Советского Союза. В обоих слу- чаях авторами этой литературы выступали специалистыкитаеведы, журналисты-международники, дипломаты, ответственные работники партийно-государственных структур; некоторые из их работ носили мемуарный характер. В самом начале $1980-x$ гг., не без влияния установок Отчетного доклада, зачитанного Л.И. Брежневым на XXV1 съезде КПСС (и в полном соответствии с этими установками) признавались определенные перемены во внутренней жизни Китая, но вместе с тем утверждалось, что официальной идеологией КНР остается маоизм, а внешняя политика по-прежнему носит ярко выраженный антисоветский характер. В эти годы не происходило какого-либо смягчения обличительного тона при рассмотрении пекинской политики, особенно международной, да и во внутренней жизни страны назывались отнюдь не одни лишь перемены к лучшему - некоторые из изменений, в т.ч. в экономической сфере, критиковались с ортодоксально-марксистских позиций. Затем, примерно с середины 1982 г. тон советской пропаганды несколько меняется, количество критических материалов по КНР существенно сокращается. Изменения в большей мере заметны по периодической печати, но и в публицистической литературе они также заявляют о себе, особенно с 1983 г. При этом изменения эти проходили неровно, в какой-то степени даже прерывисто - 1984 г., к примеру, отмечен был более жестким тоном советской пропаганды в отношении к КНР в сравнении с предыдущим годом. Приходится, в связи с этим констатировать, что ознакомившись с книгой О. Владимирова, в т.ч. с последней ее главой, советский читатель середины 1980x гг. едва ли проникся бы особым оптимизмом относительно перспектив нормализации советско-китайских отношений и, в лучшем случае, зафиксировал бы минимальное «потепление» этих отношений по сравнению с концом 1970x гг. при неизменности вывода, что полная нормализация по-прежнему тормозится Пекином и поэтому едва ли достижима в обозримом будущем.

\section{ЛИТЕРАТУРА}

1. Борисов 0.Б. Внутренняя и внешняя политика Китая в 70-е годы. Политический очерк. М.: Политиздат, 1982. 384 с.

2. Бурлацкий Ф.М. Мао Цзэдун и его наследники. М.: Международные отношения, 1980.400 с.

3. Варнаи Ф. Маоизм против мирового коммунистического движения. Пер. с венг. М.: «Политиздат», 1982. 206 с.

4. Владимиров 0. Советско-китайские отношения в сороковых - восьмидесятых годах. М.: Международные отношения, 1984. 384 с.

5. Всемирная история. Т. ХІІІ / Под ред. С.Л. Тихвинского (отв. ред.) и др. М.: Мысль, 1983.718 с.

6. Галенович Ю.М. Глобальная стратегия Китая. М.: Русская панорама, 2016. 1176 с.

7. Галенович Ю.М. За кулисами американо-китайских отношений. Полвека спустя после рукопожатия Мао и Никсона в Пекине. М.: Русская панорама, 2019. $816 \mathrm{c}$.

8. Галенович Ю.М. Китай: 40 лет спустя после Мао, 20 лет спустя после Дэна. М.: Издательский дом ВКН, 2019. 386 с.

9. Галенович Ю.М. От Сталина и Мао до Путина и Си. М.: Издательский дом ВКН, 2020. 416 с.

10. Гао Линвэй, Солнцев Н.Н. Китай: стены и люди. М.: Планета, 1981.360 с.

11. Герасимова Т.Г. 06 изучении истории КПК в СССР и России // Отечественная историография КНР: некоторые направления. М., 2015. С. 129-159.

12. Дорожкин А.Г. Антимаоистская пропаганда в СССР и советская художественная литература // Актуальные проблемы современной науки, техники и образования. Научно-технический журнал. 2019. Т. 10. № 2. С. 79-83 
13. Китай и соседи в новое и новейшее время. Отв. ред. С.Л. Тихвинский. М.: Наука, 1982. 454 с.

14. Китайская Народная республика в 1979 году: политика, экономика, идеология /под ред. М.И. Сладковского. М., 1980. 351 с.

15. Китайская Народная республика в 1980 году: политика, экономика, идеология /под ред. М.И. Сладковского. М., 1984. 256 с.

16. Кузнецов В.С. Цинская империя на рубежах Центральной Азии (вторая половина XVIII - первая половина X1Х в.). Новосибирск: Наука, 1983.127 с.

17. Кулик Б.Т. Советско-китайский раскол: причины и последствия. М.: ИДВ РАН, 2000. 640 с.

18. Кутаков Л.Н. От Пекина до Нью-Йорка. Записки советского ученого и дипломата. М.: Наука, 1983. 271 с.

19. Лазарев В.И. Классовая борьба в КНР. М.: Политиздат, 1981. 318 с.

20. Мамаева Н.Л. Советская/российская историография КНР: темы и направления // Отечественная историография КНР: некоторые направления. М, 2015. C. 24-46.

21. Материалы XXV1 съезда КПСС. М.: Политиздат, 1981. 352 с.

22. Опасный курс. Вып. 11-й. Китай после Мао Цзэдуна. М.: Политиздат, 1981. 351 с.

23. Отечественная историография КНР: некоторые направления. Под ред. Н.Л. Мамаевой и Н.И. Сотниковой - Институт Дальнего Востока РАН: М.: Наука Восточная литература. 2015. 263 с.

24. Пышков Б.М., Старостин Б.С. Пекин: в поисках «пятой колонны». М.: Политиздат, 1981. 174 с.

25. Россия и Китай: четыре века взаимодействия: история, современное состояние и перспективы развития российско-китайских отношений /

Под ред. А.В. Лукина. М.: «Весь мир», 2013. 704 с.

26. Силина Л.В. Внешнеполитическая пропаганда в СССР в 1945 - 1985 гг. (по материалам отдела пропаганды и агитации ЦК ВКП(б) - КПСС. М.: РОССПЭН, 2011. 207 C.

27. Соборов Б.А. Своевременная и полезная книга // Проблемы Дальнего Востока. 1982. № 1. С. 200-201.

28. Усов В.Н. КНР от «культурной революции» к реформам и открытости (1976 - 1984 гг.). М.: Ин-т Дальнего Востока, 2003. 189 с.

29. Федотов В.П. Полвека вместе с Китаем. Воспоминания, записи, размышления. М.: РОССПЭН, 2005. 639 С.

30. Яковлев А.Г. Внешняя политика КНР в исследованиях Института Дальнего Востока // Проблемы Дальнего Востока. 1981. № 3. С. 36-53

31. Яковлев М.И. 17 лет в Китае. М.: Политиздат, 1981.320 с.

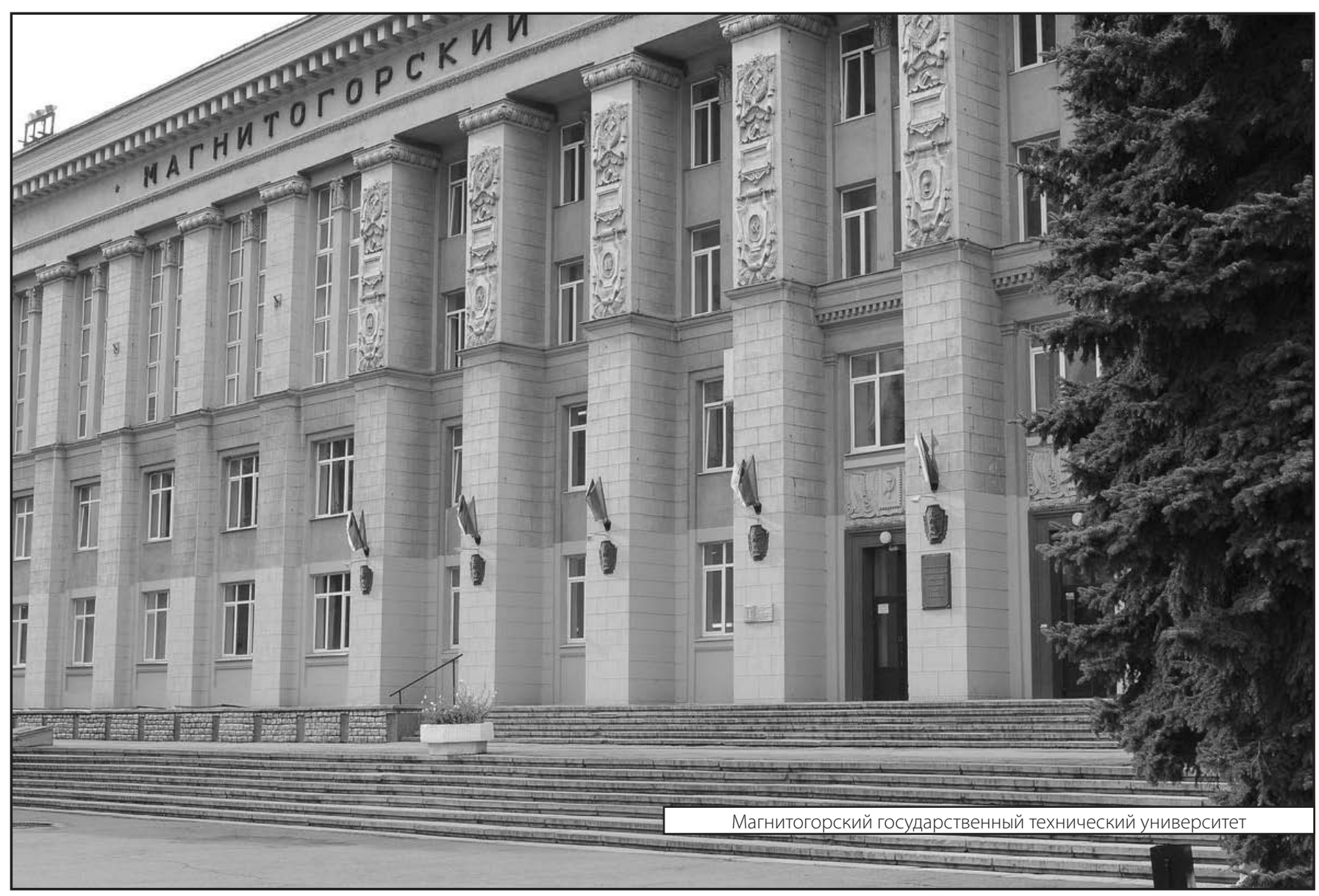

